\title{
A PERTINÊNCIA TEMÁtiCA NO CONTROLE ABSTRATO DE CONSTITUCIONALIDADE COMO REQUISITO LIMITADOR À EFETIVAÇÃO DO ACESSO À JUSTIÇA ${ }^{1}$
}

\author{
THE THEMATIC PERTINENCE IN THE ABSTRACT CONTROL OF \\ CONSTITUTIONALITY AS A LIMITING REQUIREMENT FOR EFFECTIVE ACCESS \\ TO JUSTICE
}

Olavo Augusto Vianna Alves Ferreira Doutor em Direito do Estado pela Pontifícia Universidade Católica de São Paulo (2008), Mestre em Direito do Estado pela Pontifícia Universidade Católica de São Paulo (2002). Procurador do Estado de São Paulo. Foi membro eleito do Conselho Superior da Procuradoria Geral do Estado de São Paulo. Professor Titular do Programa de Doutorado, Mestrado em Direito e graduação da UNAERP, onde atua como Coordenador Geral dos Cursos de Pós-graduação lato sensu em Direito. São Paulo/SP. Orcid: https://orcid.org/0000-0003-10674335. E-mail: olavoaferreira@hotmail.com

João Pedro Silvestrini Mestre em Direitos Coletivos e Cidadania pela Universidade de Ribeirão Preto (UNAERP). Especialista em Direito Tributário pela Faculdade de Direito de Ribeirão Preto da Universidade de São Paulo (USP). Professor de Direito do Centro Universitário Estácio Ribeirão Preto. Advogado. São Paulo/SP. Orcid: https://orcid.org/0000-0002-0581-3874. E-mail: joaopedrosilvestrini@hotmail.com

\footnotetext{
${ }^{1}$ Artigo recebido em 06/07/2021 e aprovado em 19/10/2021.
} 
Danilo Henrique Nunes

Doutorando e Mestre em Direitos Coletivos e Cidadania pela Universidade de Ribeirão Preto (UNAERP). Ribeirão Preto/SP. Centro Universitário da Fundação Educacional de Barretos, UNIFEB; Centro Universitário Estácio de Ribeirão Preto; Faculdades Metropolitanas do Estado de São Paulo, Famesp e ITES - Instituto Taguarintinguense de Ensino Superior. São Paulo/SP. Orcid: https://orcid.org/0000-0001-9162-3606. E-mail: dhnunes@hotmail.com

RESUMO: O objetivo pretendido corresponde na discussão referente à possibilidade de a pertinência temática, como jurisprudência defensiva da Suprema Corte, ocasionar em exigência jurisprudencial limitadora à efetivação do princípio do acesso à justiça. Por ser atribuição do Estado Democrático de Direito a efetivação dos direitos e garantias fundamentais, compreende-se que a pertinência temática consiste em jurisprudência inconstitucional que viola o princípio constitucional da inafastabilidade da jurisdição, previsto no artigo $5^{\circ}$, inciso XXXV, da Constituição Federal de 1988. É empregado o método hipotético-dedutivo, baseado em estudos da jurisprudência do Pretório Excelso, na Constituição Federal de 1988, na legislação infraconstitucional e na doutrina.

PALAVRAS-CHAVE: Controle abstrato de constitucionalidade; pertinência temática; acesso à justiç̧a.

ABSTRACT: The intended objective corresponds in the discussion regarding the possibility of the thematic pertinence, as Supreme Court's defensive jurisprudence, cause a jurisprudential requirement limiting the implementation of the principle of access to justice. As it is attribution of the Democratic State to enforce fundamental rights and guarantees, it is understood that the thematic pertinence consists of unconstitutional jurisprudence that violates 
the constitutional principle of the access to justice, provided for in article $5, \mathrm{XXXV}$, of the 1988 Federal Constitution. The deductive hypothetical method is used, based on studies of the jurisprudence of the Supreme Court, in the 1988 Federal Constitution, in the infraconstitutional legislation and in the doctrine.

KEYWORDS: Abstract control of constitutionality; thematic pertinence; access to justice.

\section{INTRODUÇÃO}

Com aprovação pela Assembleia Nacional Constituinte em 22 de setembro de 1988 e promulgação em 5 de outubro de 1988, a Constituição Federal de 1988 eliminou o monopólio do Procurador Geral da República ${ }^{2}$ para o ingresso das ações do controle concentrado de constitucionalidade, com a ampliação do rol de legitimados junto ao Supremo Tribunal Federal $^{3}$, promovendo, desta forma, uma democratização de acesso ao sistema de controle em tela.

Este procedimento jurídico-constitucional visa, principalmente, garantir a supremacia da Constituição, para que, desta forma, seus princípios e normas vigentes sejam atendidos ${ }^{4}$, já que pela teoria da construção escalonada de Hans Kelsen ${ }^{5}$, a Constituição está no ápice da pirâmide normativa, caracterizando-se como o fundamento de todo nosso ordenamento jurídico. Por conseguinte, uma lei infraconstitucional que não esteja em conformidade com os parâmetros constitucionais, será declarada inconstitucional.

Constata-se a evolução do controle abstrato de constitucionalidade ocorrida após a Constituição de 1988, que promoveu a ampliação dos legitimados da Ação Direta de Inconstitucionalidade, previu a Ação Direta de Inconstitucionalidade por Omissão e Arguição de Descumprimento de Preceito Fundamental, além da criação da Ação Declaratória de

\footnotetext{
${ }^{2}$ Artigo 114, I, alínea 1, da CF/67.

${ }^{3}$ Artigo 103, CF/88.

4 FERRAJOLI, Luigi. Pasado y futuro del Estado de Derecho. In: CARBONELL, Miguel (Coord.). Neoconstitucionalismo(s). Madrid: Trotta, 2003. p. 18.

${ }^{5}$ KELSEN, Hans. Teoria Pura do Direito. São Paulo: Martins Fontes, 1999. p. 155 - 156.
} 
Constitucionalidade pela Emenda Constitucional $n^{\circ}$ 03/93, culminando na edição das Leis $n^{\circ}$ 9.868/99 e n ${ }^{\circ} 9.882 / 99$.

A Lei $\mathrm{n}^{\circ}$ 9.868, de 10 de novembro de 1999, disciplinou, perante a Suprema Corte, o processo e julgamento da Ação Direta de Inconstitucionalidade e da Ação Declaratória de Constitucionalidade $^{6}$. A Lei n ${ }^{\circ}$ 9.882, de 03 de dezembro de 1999, regulamentou o processo e julgamento da Arguição de Descumprimento de Preceito Fundamental, que até este momento permanecera como letra morta ${ }^{7}$.

Atualmente, a função jurisdicional visa conferir proteção à própria ordem jurídica, independentemente da consideração de um específico fenômeno de incidência e de surgimento de relações jurídicas concretas ${ }^{8}$.

É dever de o Estado solucionar qualquer ameaça ou lesão a direitos mediante um processo imparcial e justo, sendo respeitadas as normas e garantias fundamentais, a Constituição e as leis infraconstitucionais. Esta corresponde na função jurisdicional do Estado, exercida pelo Poder Judiciário. Todavia, em decorrência desta inflação legislativa, bem como da vasta quantidade de processos que chegam anualmente ao Tribunal Maior ${ }^{9}$, e em uma interpretação restritiva, a jurisprudência do Supremo Tribunal Federal ${ }^{10}$ diferenciou os legitimados em universais e em especiais, tendo em vista a relação de pertinência temática entre os fins institucionais e o objeto de controle.

Parte de doutrina ${ }^{11}$ discorda da necessidade de se demonstrar a pertinência temática, já que implica tratamento discriminatório sem previsão constitucional e infraconstitucional,

\footnotetext{
${ }^{6}$ BARROSO, Luís Roberto. O Controle de Constitucionalidade no Direito Brasileiro. 7. ed. rev. e atual. São Paulo: Saraiva, 2016, p. 89.

${ }^{7}$ BARROSO, Luís Roberto, op. cit., p. 89.

${ }^{8}$ ZAVASCKI, Teori Albino. Processo Coletivo: Tutela de Direitos Coletivos e Tutela Coletiva de Direitos. 7. ed. rev., atual. e ampl. São Paulo: Revista dos Tribunais, 2017, p. 56.

${ }^{9}$ De 1988 à 2017, há, no Controle Abstrato de Constitucionalidade, 6.239 (seis mil duzentos e trinta e nove) processos autuados, 3.986 (três mil novecentos e oitenta e seis) processos baixados; sendo que 2.252 (dois mil duzentos e cinquenta e dois) processos encontram-se em tramitação, e 4.012 (quatro mil e doze) tiveram decisão final. In: STF. Estatísticas do STF. Disponível em: http://www.stf.jus.br/portal/cms/verTexto.asp?servico=estatistica\&pagina=CC_Geral. Acesso: 24 de ago. 2017. ${ }^{10}$ Informativo n. 307 do STF, ADI n. 2.652 - DF, e ADI n. 2.656 - SP.

${ }^{11}$ COSTA NETO, João. A abertura procedimental da jurisdição constitucional exercida pelos órgãos de cúpula: breves notas sobre Alemanha, Brasil e EUA. Revista Brasileira de Estudos Constitucionais - RBEC, Belo Horizonte, ano 6, n. 24, out./dez. 2012. $\quad$ Disponível em: http://www.bidforum.com.br/PDI0006.aspx?pdiCntd=91087. Acesso: 21/07/2017; BERNARDES, Juliano
} 
Revista Eletrônica de Direito Processual - REDP.

Rio de Janeiro. Ano 16. Volume 23. Número 1. Janeiro a Abril de 2022

Periódico Quadrimestral da Pós-Graduação Stricto Sensu em Direito Processual da UERJ

Patrono: José Carlos Barbosa Moreira (in mem.). ISSN 1982-7636. pp. 1053-1079

www.redp.uerj.br

subtraindo dos legitimados discriminados parcela da prerrogativa que o constituinte incondicionalmente lhes concedeu para promover a depuração objetiva do ordenamento jurídico.

Sob os métodos de revisão de literatura e hipotético-dedutivo, o trabalho aprofunda no tema e traz que, segundo corrente doutrinária ${ }^{12}$, devem-se ser examinados outros meios de redução dos números de processos que são encaminhados ao Supremo, pois não é passível dar interpretação restritiva a uma norma que visa proteger a própria supremacia da Constituição.

Também afirmam que a exigência da pertinência temática caracterizaria num estabelecimento de uma técnica cerrada ou numerus clausus de intérpretes da Constituição, não se garantindo, dessa forma, uma ampla democratização da interpretação constitucional ${ }^{13}$. A imposição desse requisito para estes legitimados, nomeados pela doutrina ${ }^{14}$ de especiais, configura fator limitativo da fiscalização abstrata de constitucionalidade ${ }^{15}$.

Além do rol taxativo dos legitimados aptos a ingressar com ação do controle de constitucionalidade, do artigo 103 da Lei Suprema de 1988, a pertinência temática, como uma determinação jurisprudencial defensiva da Suprema Corte, pode ocasionar em requisito limitador à efetivação do princípio da inafastabilidade da jurisdição ${ }^{16}$.

\section{O DIREITO PROCESSUAL COLETIVO BRASILEIRO E O CONTROLE ABSTRATO DA CONSTITUCIONALIDADE COMO SEU OBJETO MATERIAL}

Taveira. Controle Abstrato de Constitucionalidade: elementos materiais e princípios processuais. São Paulo: Saraiva, 2004, p. 369.

12 COSTA NETO, João, op. cit.; BERNARDES, Juliano Taveira. Controle Abstrato de Constitucionalidade op. cit., p. 369.

13 HÄBERLE, Peter. Hermenêutica Constitucional. A Sociedade Aberta dos Intérpretes da Constituição: Contribuição para a Interpretação Pluralista e "Procedimental" da Constituição. Tradução de Gilmar Ferreira Mendes. Porto Alegre: SAFE, 1997, p. 13 - 15.

${ }^{14}$ CLÈVE, Clèmerson Merlin. A Fiscalização Abstrata da Constitucionalidade no Direito Brasileiro. 2. ed. rev., atual. e ampl. São Paulo: Revista dos Tribunais, 2000. p. 168; AGRA, Walber de Moura. Aspectos Controvertidos do Controle de Constitucionalidade. Salvador: Juspodvm, 2008, p. 89; BERNARDES, Juliano Taveira. Ação Direta de Inconstitucionalidade por Omissão (ADInO). Ações Constitucionais. 5. ed. rev., atual. e ampl. Salvador: Juspodvm, 2011, p. $548-549$.

15 MENDES, Gilmar Ferreira. Jurisdição Constitucional: o Controle Abstrato de Normas no Brasil e na Alemanha. 6. ed. São Paulo: Saraiva, 2014, p. 196 - 197.

${ }^{16}$ CIANCI, Mirna; ALMEIDA, Gregório Assagra de. Direito Processual do Controle da Constitucionalidade. São Paulo: Saraiva, 2011, p. 29. 
Revista Eletrônica de Direito Processual - REDP.

Rio de Janeiro. Ano 16. Volume 23. Número 1. Janeiro a Abril de 2022

Periódico Quadrimestral da Pós-Graduação Stricto Sensu em Direito Processual da UERJ

Patrono: José Carlos Barbosa Moreira (in mem.). ISSN 1982-7636. pp. 1053-1079

www.redp.uerj.br

O Direito Processual Coletivo, caracterizado por regras e princípios gerais próprios ${ }^{17}$, pode ser especificado como disciplina processual autônoma.

Gregório Assagra de Almeida informa que o Direito Processual Coletivo:

é o ramo do direito processual que possui natureza de direito-processualconstitucional-social, cujo conjunto de normas e princípios a ele pertinente visa a disciplinar a ação coletiva, o processo coletivo, a jurisdição coletiva a defesa no processo coletivo e a coisa julgada coletiva, de forma a tutelar, no plano abstrato, a congruência do ordenamento jurídico em relação à Constituição e, no plano concreto, pretensões coletivas em sentido lato decorrentes dos conflitos coletivos ocorridos no dia a dia da conflituosidade social ${ }^{18}$.

Nosso ordenamento jurídico, no contexto da tutela jurisdicional dos direitos coletivos, propõe a classificação das tutelas processuais em consonância com as tutelas materiais, sendo necessária a existência de uma efetiva interligação entre o direito material e o processual ${ }^{19}$.

Essa relação de interligação deve ser assentada nos direitos e garantias constitucionais fundamentais ${ }^{20}$. "Se o sistema jurídico brasileiro já consagra de forma ampla a tutela jurídica material massificada, torna-se imprescindível a concepção de um direito processual massificado" $" 21$.

O Direito Processual Coletivo não nega a Teoria Geral do Processo ou a unidade do Direito Processual, as quais se baseiam no plano do Direito Processual Constitucional, mas, compreende-se que sua natureza jurídica é de Direito Processual Constitucional-Social ${ }^{22}$.

O Direito Processual Coletivo brasileiro, no âmbito do seu objeto material, divide-se em comum e especial. O Direito Processual Coletivo comum guarda relação com os direitos coletivos subjetivos (difusos, coletivos stricto sensu e individuais homogêneos), destinando-se

\footnotetext{
${ }^{17}$ Por exemplo: "a interpretação das normas sempre em benefício do grupo (quanto à legitimidade ad causam e aos poderes do juiz etc), a atenuação do princípio do dispositivo e do princípio da estabilização da demanda, um novo conceito de indisponibilidade objeto e subjetiva, uma maior liberdade das formas" (CINTRA, Antônio Carlos Araújo; DINAMARCO, Cândido Rangel; GRINOVER, Ada Pellegrini. Teoria Geral do Processo. 21. ed. rev. e atual. São Paulo: Malheiros, 2005, p. 133).

18 ALMEIDA, Gregório Assagra de. Direito Processual Coletivo Brasileiro: um Novo Ramo do Direito Processual. São Paulo: Saraiva, 2003, p. 22.

${ }^{19}$ CIANCI, Mirna; ALMEIDA, Gregório Assagra de, op. cit., p. 82.

${ }^{20}$ MARINONI, Luiz Guilherme. Técnica Processual e Tutela dos Direitos. São Paulo: Revista dos Tribunais, 2004, p. 27.

${ }^{21}$ CIANCI, Mirna; ALMEIDA, Gregório Assagra de, op. cit., p. 82.

${ }^{22}$ ALMEIDA, Gregório Assagra de, op. cit., p. 18 - 19.
} 
a solução de conflitos coletivos ou de dimensão coletiva ocorridos no plano da concretude, consistindo em instrumento de efetivação da Constituição, Estado Democrático de Direito e dos direitos e garantias fundamentais ${ }^{23}$. São ações do Direito Processual Coletivo comum, dentre outras, a Ação Civil Pública, o Mandado de Segurança Coletivo e a Ação Popular, por exemplo.

O Direito Processual Coletivo especial possui como objeto material a tutela de interesse coletivo legítimo, destinando-se ao controle abstrato de constitucionalidade via: Ação Declaratória de Constitucionalidade, Ação Direta de Inconstitucionalidade, Ação Direta de Inconstitucionalidade por omissão, Arguição de Descumprimento de Preceito Fundamental, que constituem ações do processo coletivo segundo a doutrina de Gregório Assagra de Almeida e Mirna Cianci $^{24}$ e Teori Albino Zavascki ${ }^{25}$, conforme será explicado no item seguinte. Nesse procedimento, não há a defesa de direitos subjetivos.

A tutela é apenas de direito objetivo, ao se confrontar determinada lei ou ato normativo primário em face da Carta Constitucional. Esse procedimento visa garantir, no plano abstrato, a supremacia da Constituição, no que se refere ao Estado Democrático de Direito, combatendo possíveis normas inconstitucionais.

O Poder Judiciário, na fiscalização abstrata de constitucionalidade, exerce a função jurisdicional visando, especialmente, a defesa da ordem constitucional através da resolução de controvérsias sobre a legitimidade da norma jurídica abstratamente considerada, independentemente de sua incidência em específicos suportes fáticos, e não a tutela de direitos subjetivos ${ }^{26}$.

$\mathrm{Na}$ Ação Direta de Inconstitucionalidade $\mathrm{n}^{\circ} 5.832 / \mathrm{DF}^{27}$, o Tribunal Maior afirmou que a Associação Nacional das Operadoras Celulares e a Associação Brasileira de Concessionárias

\footnotetext{
${ }^{23}$ CIANCI, Mirna; ALMEIDA, Gregório Assagra de, op. cit., p. 82 - 83. SILVESTRINI, João Pedro; GERAIGE NETO, Zaiden; VILELA, Thiago Ribeiro Franco. A Contribuição do Código de Defesa do Consumidor na Tutela de Interesses Individuais e Coletivos. Revista Direito e Justiça: Reflexões Sociojurídicas. Santo Ângelo, v. 19, n. 34, p. 97 - 112, maio/agos. 2019, p. $106-107$.

${ }^{24}$ CIANCI, Mirna; ALMEIDA, Gregório Assagra de, op. cit., p. 82 - 83.

${ }^{25}$ ZAVASCKI, Teori Albino. Processo Coletivo, op. cit., p. 55 - 57.

${ }^{26}$ Id., Ibid., p. 249.

27 Nesse caso, por unanimidade, o Pretório Excelso julgou procedente o pedido para declarar a inconstitucionalidade formal da Lei $\mathrm{n}^{\circ}$ 5.972, de 18 de agosto de 2017.
} 
de Serviço Telefônico Fixo Comutado possuem legitimidade ad causam para ajuizar Ação Direta de Inconstitucionalidade contra norma que determinou que as empresas fornecedoras de serviço de comunicação multimídia devem compensar os consumidores pela suspensão de serviço ou pelo provimento de velocidade inferior à contratada.

O Estado Democrático de Direito visa solucionar eventuais imprecisões, ambiguidades e insuficiências transformadoras do Estado Social de Direito ${ }^{28}$. Objetiva a renovação com justiça da realidade social, mediante a efetivação dos direitos fundamentais e da defesa ampla e irrestrita aos direitos individuais e coletivos ${ }^{29}$.

Como guardiã da Constituição, o Supremo Tribunal Federal deve fundamentar suas decisões nos direitos e garantias fundamentais e nos preceitos constitucionais elementares e inerentes ao Estado Democrático de Direito, nos termos dos artigos $1^{\circ}$ e 102 da Lei Suprema de 1988. Conforme exigência expressa da Constituição Federal de 1988, em seu artigo $3^{\circ}$, incisos I e III, compete ao STF a garantia do maior compromisso do Estado Democrático de Direito: a transformação com justiça da realidade social ${ }^{30}$.

Em suma, o sistema de controle abstrato da constitucionalidade, em se tratando de direitos coletivos, configura um mecanismo extremamente relevante para a garantia da rigidez e supremacia constitucional, tal como para a efetividade da democracia ${ }^{31}$.

A determinação da comprovação da pertinência temática, pela jurisprudência defensiva do Supremo Tribunal Federal, pelos legitimados especiais, ocasiona em certa quebra na "democracia participativa" 32 , pois, obsta o ingresso da ação de fiscalização abstrata de constitucionalidade por esses representantes.

\footnotetext{
${ }^{28}$ LUÑO, Antonio E. Pérez. Derechos Humanos, Estado de Derecho e Constitución. 2. ed. Madrid: Tecnos, 1986. p. 229

${ }^{29}$ NUNES, Danilo Henrique; SILVEIRA, Sebastião Sérgio. A Banalização dos Princípios da Razoabilidade e da Proporcionalidade no Controle Difuso de Constitucionalidade e Separação de Poderes. Revista Eletrônica de Direito Processual-REDP. Rio de Janeiro, ano 13, vol. 20, n. 2, p. 74 - 95, Mai./Ago. 2019, p. 77 - 78.

${ }^{30}$ ALMEIDA, Gregório Assagra de, op. cit., p. 235 - 236.

${ }^{31}$ ZAVASCKI, Teori Albino. Processo Coletivo, op. cit., p. 55 - 57; CIANCI, Mirna; ALMEIDA, Gregório Assagra de, op. cit., p. $82-83$.

${ }^{32}$ CANOTILHO, J. J. Gomes. Direito Constitucional e Teoria da Constituição. 7. ed. Coimbra: Almedina, 2007,p. $287-288$.
} 
3. A TUTELA JURISDICIONAL DOS DIREITOS COLETIVOS NO CONTROLE ABSTRATO DE CONSTITUCIONALIDADE E INAFASTABILIDADE DA JURISDIÇÃO

Pela análise do princípio da inafastabilidade da jurisdição, previsto no artigo $5^{\circ}$, inciso XXXV, da Constituição Federal de 1988, entende-se que a função jurisdicional estatal é empregada, frequentemente, com o intuito de tutelar qualquer ameaça ou lesão a direitos.

Nesse sentido, o princípio do acesso à justiça obteve previsão expressa no artigo $3^{\circ}$, caput, do Código de Processo Civil de 2015: "Não se excluirá da apreciação jurisdicional ameaça ou lesão a direito". Este princípio é considerado como imperativo ético do Estado Democrático de Direito, nos termos do artigo 10 da Declaração Universal dos Direitos Humanos de $1948^{33}$.

Com fulcro no acesso universal ao Poder Judiciário e no princípio da inafastabilidade do controle jurisdicional, compreende-se ser uma garantia fundamental das pessoas a proteção ou reparação de seus direitos, por intermédio de uma ordem jurídica justa. Este princípio deve ser observado na garantia dos direitos difusos e coletivos, não somente aos direitos individuais, pois todas as pessoas podem postular, ao Poder Judiciário, tutela jurisdicional preventiva ou reparatória ${ }^{34}$. "Referido princípio tem por objetivo assegurar o direito a uma tutela jurisdicional a todos que dela necessitem. Trata-se, portanto, do princípio que garante às pessoas, tanto naturais como jurídicas, quer de direito público ou privado"35.

A jurisdição corresponde ao encargo do Estado em declarar, por meio do Poder Judiciário, a vontade legal perante uma situação controvertida. É direito do homem a intervenção do Poder Público para solucionar a lide e efetivar a justiça ${ }^{36}$. "O conceito de

\footnotetext{
33 "Art. 10: Toda pessoa tem direito, em condições de plena igualdade, de ser ouvida publicamente e com equidade, por um tribunal independente e imparcial, para a determinação de seus direitos e obrigações, ou para o exame de qualquer acusação contra ela dirigida, em matéria penal"

${ }^{34}$ NERY JR., Nelson. Princípios do Processo Civil na Constituição Federal. 7. ed. rev. e atual. São Paulo: Editora Revista dos Tribunais, 2002, p. 100.

35 DANTAS, Paulo Roberto de Figueiredo. Direito Processual Constitucional. 5. ed. rev. e amp. São Paulo: Atlas, 2014, p. 29.

${ }^{36}$ BOBBIO, Norberto. A Era dos Direitos. Tradução de Carlos Nelson Coutinho. Rio de Janeiro: Elsevier, 2004, p. 42.
} 
jurisdição, consequentemente, está relacionado com a atividade estatal de identificar e fazer atuar a norma jurídica em casos concretos, vale dizer, a partir da verificação da ocorrência (ou da iminência) de uma situação de fato" ${ }^{37}$.

A tutela jurisdicional também pode ser delineada como o direito que todo pessoa detém para que, mediante um processo que se garanta a justiça e a imparcialidade, sua lide seja solucionada ${ }^{38}$. É direito dos jurisdicionados obter, do Poder Judiciário, uma tutela jurisdicional adequada e justa ${ }^{39}$.

Giuseppe Chiovenda ${ }^{40}$ define a jurisdição como obrigação do Estado em prezar pela vontade concreta das leis, mediante atividade dos particulares e dos órgãos públicos em ratificarem a Constituição, tornando-a efetiva. Já para Piero Calamandrei, o caráter e o desígnio jurisdicional consistem em "fazer observar o direito objetivo em seus preceitos individualizados" ${ }^{\prime 4}$.

Pelo processo ser considerado "um instrumento a serviço da paz social" ${ }^{42}$, a jurisdição também pode ser convocada com a ideia de se tutelar direitos difusos e direitos coletivos, ambos de titularidade indeterminada, pois conforme nossa Carta Constitucional de 1988, a função jurisdicional objetiva, especialmente, a defesa do ordenamento jurídico, independentemente de avaliação de um fenômeno específico de incidência e de surgimento de relações jurídicas concretas ${ }^{43}$.

Constata-se, assim, a jurisdição constitucional exercida pelo Pretório Excelso no controle de constitucionalidade das leis e atos normativos primários visando a aplicação da Constituição ${ }^{44}$. "Trata-se de atuação objetivando dar efetividade à ordem jurídica

\footnotetext{
${ }^{37}$ ZAVASCKI, Teori Albino. Processo Coletivo, op. cit., p. 55.

${ }^{38}$ PÉREZ, Jesús González. El Derecho a la Tutela Jurisdiccional. 2. ed. Madrid: Civitas, 1989, p. 27.

${ }^{39}$ NERY JR., Nelson, op. cit., p. 100 - 101.

${ }^{40}$ CHIOVENDA, Giuseppe. Instituições de Direito Processual Civil. Tradução de J. Guimarães Menegale. 3. ed. São Paulo: Saraiva, 1969.

${ }^{41}$ CALAMANDREI, Piero. Instituciones de Derecho Procesal Civil. v. 1. Tradução de Santiago Sentis Melendo. Buenos Aires: EJEA, 1986, p. 178.

${ }^{42}$ LIMA, Rogério Medeiros Garcia de. Processo Civil e Direitos Fundamentais. Revista Paradigma. Ribeirão Preto/SP, a. XX, v. 24, n. 2, p. 57 - 70, Jul./Dez. 2015, p. 64.

${ }^{43}$ ZAVASCKI, Teori Albino. Processo Coletivo, op. cit., p. 56.

${ }^{44}$ BARROSO, Luís Roberto, op. cit., p. 383.
} 
abstratamente considerada, em processo em que não há lide nem, consequentemente, partes, no sentido com que tal terminologia é adotada pelo Código de Processo" 45.

Teori Albino Zavascki explica que, além de possuírem eficácia direta na defesa da supremacia da Constituição, indiretamente, as sentenças de mérito, proferidas nas ações de fiscalização abstrata de constitucionalidade, podem autorizar ou não a incidência da norma objeto da ação sobre os fatos jurídicos ${ }^{46}$.

As decisões de mérito proferidas nas ações de controle de constitucionalidade consistem em um procedimento especial de prestar a tutela coletiva de direitos, possuindo a eficácia de, diretamente, prestar a defesa a ordem jurídica, e indiretamente, de autorizar ou desautorizar a incidência de uma norma, objeto da ação, sobre os fatos jurídicos, afirmando ou não a subsistência dos direitos subjetivos ${ }^{47}$.

De acordo com Mirna Cianci e Gregório Assagra de Almeida ${ }^{48}$, o sistema constitucional do controle das leis e atos normativos primários, pelo Supremo Tribunal Federal, é imprescindível para a garantia da supremacia e rigidez da Constituição e para a efetividade da ordem democrática. Flávia Piovesan ${ }^{49}$ acrescenta que "a Carta Constitucional será destituída de força jurídica vinculante se ela for desprovida de um sistema eficaz de eliminação de inconstitucionalidades".

O Poder judiciário deve assegurar a integridade dos direitos objetivos, quando esses forem lesados ${ }^{50}$. Considerando-se essa circunstância, e a eficácia ex tunc, sob o enfoque material, e erga omnes, em sua dimensão subjetiva, torna-se inegável que o sistema do controle abstrato de constitucionalidade estabelece importante mecanismo para tutelar não apenas o ordenamento jurídico, mas também direitos subjetivos individuais, mesmo que indiretamente, em virtude da eficácia vinculante das decisões ${ }^{51}$.

\footnotetext{
45 ZAVASCKI, Teori Albino. Processo Coletivo, op. cit., p. 56.

${ }^{46}$ Id., Ibid., p. 57.

${ }^{47}$ Id., Ibid., p. 249.

${ }^{48}$ CIANCI, Mirna; ALMEIDA, Gregório Assagra de, op. cit., p. 84 - 85.

${ }^{49}$ PIOVESAN, Flávia. Proteção Judicial contra Omissões Legislativas: Ação Direta de Inconstitucionalidade por Omissão e Mandado de Injunção. São Paulo: Revista dos Tribunais, 1995, p. 73 - 74.

${ }^{50}$ ROSAS, Roberto. Direito Processual Constitucional: princípios constitucionais do processo civil. 2. ed. rev., atual. e ampl. São Paulo: Editora Revista dos Tribunais, 1997, p. 29.

51 ZAVASCKI, Teori Albino. Processo Coletivo, op. cit., p. 249.
} 
Faz-se atuar a jurisdição com o objetivo principal de defender a supremacia da Constituição, através da solução de controvérsias que versem sobre a legitimidade da norma jurídica abstratamente considerada, sendo os direitos coletivos tutelados indiretamente ${ }^{52}$.

Soraya Lunardi ${ }^{53}$ aponta ser praticamente impossível promover uma ação de controle de constitucionalidade se determinada norma ou ator normativo primário não estiver provocando prejuízos a pessoas ou grupo de pessoas. Em virtude de suas importantes consequências sociais, o Poder Judiciário deve priorizar, em todos os seus níveis, a proteção dos direitos coletivos, pois a sua falta ou violação pode retirar o valor substancial da democracia e deslegitimar, pela omissão, a atuação estatal ${ }^{54}$. Portanto, concordamos com a doutrina $^{55}$ que classifica as ações de controle abstrato de constitucionalidade como mecanismo de tutela coletiva de direitos.

Os legitimados universais e especiais previstos no rol taxativo do artigo 103, da Constituição Federal de 1988, devem atuar institucionalmente, com o intuito de preservar o sistema constitucional. Contudo, as ações do controle abstrato de constitucionalidade que visam tutelar de direitos coletivos, por autoria dos órgãos ou entidades do artigo 103, incisos IV, V e IX, da Constituição Federal de 1988, estão sujeitas ao crivo jurisprudencial da pertinência temática pela Suprema Corte ${ }^{56}$.

Com o devido respeito, é possível inferir que a imposição da pertinência temática, como jurisprudência defensiva do Supremo Tribunal Federal, caracteriza ofensa ao princípio constitucional da inafastabilidade da jurisdição, previsto no artigo $5^{\circ}$, inciso $\mathrm{XXXV}$, da Constituição Federal de 1988, já que, além da previsão do rol taxativo do artigo 103, da Carta Magna de 1988, para ingresso com ação do controle abstrato de constitucionalidade, a pertinência temática dificulta aos legitimados especiais a propositura de ações neste procedimento.

\footnotetext{
${ }^{52}$ Id., Ibid., loc. cit.

${ }^{53}$ LUNARDI, Soraya. Teoria do Processo Constitucional: Análise de sua Autonomia, Natureza e Elementos. São Paulo: Atlas, 2013, p $121-122$.

${ }^{54}$ CIANCI, Mirna; ALMEIDA, Gregório Assagra de, op. cit., p. 31.

55 ZAVASCKI, Teori Albino. Processo Coletivo, op. cit., p. 55 - 57; CIANCI, Mirna; ALMEIDA, Gregório Assagra de, op. cit., p. $82-83$.

${ }^{56}$ Informativo n. 307 do STF, ADI n. 2.652 - DF, e ADI n. 2.656 - SP.
} 
Conforme Juliano Taveira Bernardes ${ }^{57}$, como a pertinência temática não decorre de nenhuma norma constitucional, nem mesmo de alguma não textual, não se poderiam estabelecer freios através de jurisprudência restritiva que prejudicassem a abertura do acesso ao processo de controle abstrato de constitucionalidade. A exigência da pertinência temática, como jurisprudência defensiva da Suprema Corte, configura verdadeira inoperância da função jurisdicional estatal para a defesa de direitos coletivos, prejudicando a efetivação da cidadania $^{58}$.

A tutela jurídica dos direitos coletivos, no Estado Democrático de Direito, deve ser ampla e irrestrita, pois seu objetivo não consiste apenas na declaração de direitos, mas sim na efetivação destes, com justiça, da realidade social ${ }^{59}$. Gregório Assagra de Almeida ${ }^{60}$ afirma que no Estado Democrático de Direito que deve haver uma plena efetivação dos direitos coletivos, através da proteção abstrata dos direitos fundamentais e da consequente observância ao princípio constitucional da inafastabilidade da jurisdição, previsto no artigo $5^{\circ}$, inciso XXXV, da Carta Magna de 1988.

É o que se tem em comento, considerando a defesa dos direitos coletivos para a concreção da cidadania.

\section{DO POSICIONAMENTO ADOTADO}

A pertinência temática decorre de uma construção jurisprudencial defensiva que visa diminuir o número de Ações Diretas ajuizadas na Suprema Corte e baseia-se na exigência de comprovação da relação de pertinência entre o objeto da ação e as finalidades institucionais dos legitimados do artigo 103, incisos IV, V e IX, da Constituição Federal de 1988, para o ingresso de ação do controle abstrato de constitucionalidade ${ }^{61}$.

\footnotetext{
${ }^{57}$ BERNARDES, Juliano Taveira. Controle Abstrato de Constitucionalidade, op. cit., p. 369.

${ }^{58}$ ALMEIDA, Gregório Assagra de, op. cit., p. 58; CIANCI, Mirna; ALMEIDA, Gregório Assagra de, op. cit., p. 29.

${ }^{59}$ CIANCI, Mirna; ALMEIDA, Gregório Assagra de, op. cit., p. 29.

${ }^{60}$ ALMEIDA, Gregório Assagra de, op. cit., p. 58.

${ }^{61}$ FERREIRA, Olavo Augusto Vianna Alves. Controle de Constitucionalidade e seus Efeitos. 3. ed. rev. e atual. Salvador: JusPODIVM, 2016, p. $59-60$.
} 
Revista Eletrônica de Direito Processual - REDP.

Rio de Janeiro. Ano 16. Volume 23. Número 1. Janeiro a Abril de 2022

Periódico Quadrimestral da Pós-Graduação Stricto Sensu em Direito Processual da UERJ

Patrono: José Carlos Barbosa Moreira (in mem.). ISSN 1982-7636. pp. 1053-1079

www.redp.uerj.br

A comprovação da relação de pertinência pelos legitimados especiais ocasiona em certa quebra na "democracia participativa"62, pois dificulta aos legitimados especiais o ingresso de ação do controle abstrato de constitucionalidade que visa tutelar direitos coletivos $^{63}$.

A pertinência temática implica em tratamento discriminatório em relação aos legitimados que a ela não se sujeitam, "subtraindo dos legitimados descriminados parcela da prerrogativa que o constituinte incondicionalmente lhes concedeu para promover a depuração objetiva do ordenamento jurídico" ${ }^{64}$. A exigência jurisprudencial do instituto, pela Suprema Corte, estabelece uma restrição não prevista em lei, afastando-se a observância do princípio hermenêutico segundo o qual ubi lex non distinguit nec nos distinguere debemus (onde a lei não distingue, não pode o intérprete distinguir) ${ }^{65}$. Portanto, não incumbe ao intérprete limitar direitos que a Constituição ou legislador não restringe.

O requisito jurisprudencial da pertinência temática constitui limitação sem fundamento expresso estabelecido pela Constituição, acarretando flagrante de inconstitucionalidade por limitação indevida ${ }^{66}$ sem respaldo em norma legal, bem como em uma atuação ativista pelo Pretório Excelso. Elival da Silva Ramos define por ativismo judicial "o exercício da função jurisdicional, pelo Poder Judiciário, para além dos limites impostos pela legislação constitucional e infraconstitucional, resolvendo litígios de feições subjetivas (conflitos de interesse) e controvérsias jurídicas de natureza objetiva (conflitos normativos) ${ }^{967}$.

\footnotetext{
${ }^{62}$ CANOTILHO, J. J. Gomes, op. cit., p. $287-288$.

${ }^{63}$ ZAVASCKI, Teori Albino. Processo Coletivo, op. cit., p. 55 - 57; CIANCI, Mirna; ALMEIDA, Gregório Assagra de, op. cit., p. $82-83$.

${ }^{64}$ BERNARDES, Juliano Taveira. Controle Abstrato de Constitucionalidade, op. cit., p. 370.

${ }^{65}$ MAXIMILIANO, Carlos. Hermenêutica e aplicação do direito. Rio de Janeiro: Forense, 1999, p. 247.

${ }^{66}$ Em consonância a este entendimento, João Ribeiro Costa Neto também afirma que estas e outras exigências revelam uma tendência do STF em dificultar o acesso à Corte. In: A abertura procedimental da jurisdição constitucional exercida pelos órgãos de cúpula: breves notas sobre Alemanha, Brasil e EUA. Revista Brasileira de Estudos Constitucionais - RBEC, Belo Horizonte, ano 6, n. 24, out./dez. 2012. Disponível em: http://www.bidforum.com.br/PDI0006.aspx?pdiCntd=91087. Acesso: 21/07/2017.

${ }^{67}$ RAMOS, Elival da Silva. Ativismo Judicial: Parâmetros Dogmáticos. São Paulo: Saraiva, 2010. p. 129.
} 
Revista Eletrônica de Direito Processual - REDP.

Rio de Janeiro. Ano 16. Volume 23. Número 1. Janeiro a Abril de 2022

Periódico Quadrimestral da Pós-Graduação Stricto Sensu em Direito Processual da UERJ

Patrono: José Carlos Barbosa Moreira (in mem.). ISSN 1982-7636. pp. 1053-1079 www.redp.uerj.br

$\mathrm{O}$ ativismo judicial, de acordo com o The Oxford Companion to the Supreme Court of the United States, remete à atuação do Poder Judiciário que ultrapassa os poderes a ele outorgado, em oposição à autocontenção judicial ${ }^{68}$.

Luís Roberto Barroso informa que "a noção de ativismo judicial está relacionada a uma atuação mais intensa e ampla do Judiciário na efetivação das finalidades constitucionais, mediante a interferência na esfera de atuação dos outros dois Poderes" ${ }^{69}$.

Há uma expansão do espaço tradicional do Poder Judiciário, na defesa da supremacia da Constituição e dos direitos e garantias fundamentais ${ }^{70}$. Geralmente, o ativismo se instala nos casos de retração do Poder Legislativo, correspondendo a um modo específico e proativo de interpretar a Constituição ${ }^{71}$. Essa função se assemelha à de elaboração do próprio direito, distanciando os juízes e tribunais de sua função típica de aplicação do ordenamento jurídico ${ }^{72}$.

No ativismo judicial, observa-se verdadeira "ultrapassagem das linhas demarcatórias da função jurisdicional, em detrimento principalmente da função legislativa, mas também, da função administrativa e até mesmo, da função de governo" 73 .

Por conta deste fenômeno, qual seja o do ativismo do Poder Judiciário, não há uma democrática judicialização das decisões mais relevantes, mas sim uma hipertrofia do sistema jurídico sobre o sistema político ${ }^{74}$. Há, no Brasil, inúmeros precedentes que demonstram a conduta ativista do Pretório Excelso:

a) a aplicação direta da Constituição a situações não expressamente contempladas em seu exto e independentemente de manifestação do

\footnotetext{
${ }^{68}$ HALL, Kermit L. (Ed.). The Oxford Companion to the Supreme Court of the United States. New York: Oxford University Press, 1992, p. 454.

${ }^{69}$ BARROSO, Luís Roberto, op. cit., p. 389. No mesmo sentido: TRINDADE, André Karam; OLIVEIRA, Rafael Tomaz de. O Ativismo Judicial na Débâcle do Sistema Político: sobre uma hermenêutica da crise. Revista Eletrônica do Curso de Direito da UFSM, Santa Maria, RS, v. 11, n. 2, p. 751 - 772, 2016, p. 759.

${ }^{70}$ TAVARES, André Ramos. Paradigmas do Judicialismo Constitucional. São Paulo: Saraiva, 2012 , p. 65 - 66.

${ }^{71}$ BARROSO, Luís Roberto, op. cit., p. 390; KMIEC, Keenan D. The Origin and Current Meanings of "Judicial Activism”. California Law Review, v. 92, n. 5, p. 1441 - 1477, 2004. p. 1442 - 1444.

${ }^{72}$ MARSHALL, William P. Conservatism and the Seven Signs of Judicial Activism. University of Colorado Law Review, Chapel Hill, n. 73, p. 101 - 140, 2002; BARROSO, Luís Roberto, op. cit., p. 390; GREEN, Craig. An Intellectual History of Judicial Activism. Emory Law Journal, Atlanta, v. 58, n. 5, p. 1195 - $1263,2009$.

${ }^{73}$ RAMOS, Elival da Silva. Ativismo Judicial, op. cit., p. 116. No mesmo sentido: BLACK, Henry Campbell. Black's Law Dictionary. 5. ed. St. Paul: West Group, 1983. p. 440; MERRIAM-WEBSTER. Merriam-Webster's Dictionary of Law. Massachusetts: Merriam-Webster, 1996. p. 270; WALDRON, Jeremy. A Right-Based Critique of Constitutional Rights. Oxford Journal of Legal Studies, v. 13, n. 1, p. 18-51, 1993. p. 45.

74 TAVARES, André Ramos. Paradigmas do Judicialismo Constitucional, op. cit., p. 65.
} 
Revista Eletrônica de Direito Processual - REDP.

Rio de Janeiro. Ano 16. Volume 23. Número 1. Janeiro a Abril de 2022

Periódico Quadrimestral da Pós-Graduação Stricto Sensu em Direito Processual da UERJ

Patrono: José Carlos Barbosa Moreira (in mem.). ISSN 1982-7636. pp. 1053-1079

www.redp.uerj.br

legislador ordinários, como se passou em casos como o da imposição de fidelidade partidária e o de vedação do nepotismo; b) a declaração de inconstitucionalidade de atos normativos emanados do legislador, com base em critérios menos rígidos que os de patente e ostensiva violação da Constituição, de que são exemplos as decisões referentes à verticalização das coligações partidárias e à cláusula de barreira; c) a imposição de condutas ou de abstenções ao Poder Público, tanto em caso de inércia do legislador como no precedente de greve do serviço público ou sobre criação de município - como no de políticas públicas insuficientes, de quem tem sido exemplo as decisões sobre o direito à saúde ${ }^{75}$.

Michael J. Perry advoga pelo minimalismo judicial ou originalismo, afirmando que deve haver pouco espaço para o subjetivismo do Juiz, para que, assim, a Justiça Constitucional seja menos política e mais jurídica ${ }^{76}$.

André Ramos Tavares indica não haver qualquer incompatibilidade entre o originalismo e o controle judicial de constitucionalidade, mas apenas um problema de grau, de intensidade da atividade judicial ${ }^{77}$. Segundo o referido autor, o "originalismo pretende que apenas por meio de sua concepção é que se pode legitimar o controle judicial de constitucionalidade" 78 .

O minimalismo judicial proporciona mais segurança na interpretação das normas constitucionais, sustentando a supremacia da Constituição ${ }^{79}$.

A imposição do requisito jurisprudencial da pertinência temática, em virtude da ausência legal, aos legitimados especiais do artigo 103, incisos IV, V e IX, da Constituição Federal de 1988, para o ingresso de ação do controle abstrato de constitucionalidade, configura certo ativismo judicial exercido pela Suprema Corte ${ }^{80}$.

Essa discricionariedade, com a imposição da pertinência temática, afeta e altera a lógica de um processo democrático, em razão da inobservância de um devido procedimento

\footnotetext{
${ }^{75}$ BARROSO, Luís Roberto, op. cit., p. 389 - 390.

${ }^{76}$ PERRY, Michael J. The Constitution in the Courts: Law or Politics? New York/Oxford: Oxford University Press, 1994. p. 54. Igualmente: YOUNG, Ernest A. Judicial Activism and Conservative Politics. University of Colorado Law Review, v. 73, n. 4, p. 1139 - 1216, 2002; ULLA, Juan Manuel López. Orígenes Constitucionales del Control Judicial de las Leyes. Madrid: Editorial Tecnos, 1999, p. 26.

77 TAVARES, André Ramos. Paradigmas do Judicialismo Constitucional, op. cit., p. 75 - 76.

${ }^{78}$ Id., Ibid., p. 76.

${ }^{79}$ PERRY, Michael J., op. cit., p. 54; TAVARES, André Ramos. Paradigmas do Judicialismo Constitucional, op. cit., p. $75-76$.

${ }^{80}$ TAVARES, André Ramos. Paradigmas do Judicialismo Constitucional, op. cit., p. 60 - 66; BERNARDES, Juliano Taveira. Controle Abstrato de Constitucionalidade, op. cit., p. 370; MENDES, Gilmar Ferreira. Jurisdição Constitucional, op. cit., p. 196 - 199.
} 
Revista Eletrônica de Direito Processual - REDP.

Rio de Janeiro. Ano 16. Volume 23. Número 1. Janeiro a Abril de 2022

Periódico Quadrimestral da Pós-Graduação Stricto Sensu em Direito Processual da UERJ

Patrono: José Carlos Barbosa Moreira (in mem.). ISSN 1982-7636. pp. 1053-1079

www.redp.uerj.br

constitucional de legislar ${ }^{81}$. Conforme Elival da Silva $\operatorname{Ramos}^{82}$, esta atuação ativista da Suprema Corte, distanciando-se de critérios hermenêuticos claros viola o postulado básico de Estado Democrático de Direito.

A fiscalização abstrata de constitucionalidade, em se tratando de direitos coletivos, configura um mecanismo extremamente relevante para a garantia da rigidez e supremacia constitucional, tal como para a efetividade da democracia ${ }^{83}$. O controle da constitucionalidade das leis e atos normativos consiste em defesa objetiva dos direitos fundamentais, dos direitos coletivos e da Constituição ${ }^{84}$.

Zaiden Geraige Neto explica que o "dispositivo do inc. XXXV do art. 5 da CF é um princípio constitucional, uma garantia ao jurisdicionado, um verdadeiro sustentáculo do Estado Social e Democrático de Direito" ${ }^{\text {85. }}$.

Este princípio constitucional é observado não apenas sob o enfoque de acesso ao Poder Judiciário, mas também a uma tutela jurisdicional adequada ${ }^{86}$.

Kazuo Watanabe assevera que o princípio da inafastabilidade do controle jurisdicional assegura o acesso a uma ordem jurídica justa e a uma tempestiva e efetiva proteção contra qualquer forma de denegação da justiça ${ }^{87}$.

O princípio constitucional da inafastabilidade do controle jurisdicional configura garantia processual imprescindível contra arbitrariedades por parte de legisladores ou outras

${ }^{81}$ BARROSO, Luís Roberto, op. cit., p. 389 - 390.

${ }^{82}$ RAMOS, Elival da Silva. Ativismo Judicial, op. cit., p. 103. No mesmo sentido: TRINDADE, André Karam. O Ativismo Judicial à Brasileira e a Questão Penitenciária no Rio Grande do Sul. Revista da Faculdade de Direito do Sul de Minas, Pouso Alegre, v. 32, n. 1, p. 203 - 228, jan./jun. 2016, p. 205 - 212.

${ }^{83}$ CIANCI, Mirna; ALMEIDA, Gregório Assagra de, op. cit., p. 29 - 31; ZANDONA, Sérgio Henriques; CAMPOS, Felipe Almeida. A Crise do Sistema Representativo na Tutela Processual Coletiva Brasileira. Revista Paradigma. Ribeirão Preto/SP, a. XXIV, v. 28, n. 1, p. 57 - 81, Jan./Abr. 2019, p. 75 - 76.

${ }^{84}$ TAVARES, André Ramos. Teoria da Justiça Constitucional. São Paulo: Saraiva, 2005, p. 287 - 288.

${ }^{85}$ GERAIGE NETO, Zaiden. O Princípio da Inafastabilidade do Controle Jurisdicional: art. $5^{\circ}$, inciso XXXV, da Constituição Federal. São Paulo: Revista dos Tribunais, 2003, p. 72.

${ }^{86}$ FERREIRA, Olavo Augusto Vianna Alves; BORGES, Daniela Meca. A Limitação Territorial da Coisa Julgada como Óbice ao Acesso à Justiça. Revista Opinião Jurídica. Fortaleza, ano 16, n. 23, p. 160 - 183, Jul./Dez. 2018, p. $166-167$.

${ }^{87}$ Tutela antecipatória e Tutela Específica das Obrigações de Fazer e de Não Fazer. In: TEIXEIRA, Min. Sálvio Figueiredo (Coord.). Reforma do Código de Processo Civil. São Paulo: Saraiva, 1996, p. 19 - 20 . No mesmo sentido: MONTESANO, Luigi. La Garanzia Costituzionale del Contraddittorio e i Giudizi Civili di "Terza Via". Rivista di Diritto Processuale. Padova, v. 55, n. 4, p. 929 - 947, out. 2000; COMOGLIO, Luigi Paolo. Garanzie Costituzionali e "Giusto Processo" (modelli a confronto). Revista de Processo. São Paulo, vol. 90, p. 95 - 150, 1998. 
Revista Eletrônica de Direito Processual - REDP.

Rio de Janeiro. Ano 16. Volume 23. Número 1. Janeiro a Abril de 2022

Periódico Quadrimestral da Pós-Graduação Stricto Sensu em Direito Processual da UERJ

Patrono: José Carlos Barbosa Moreira (in mem.). ISSN 1982-7636. pp. 1053-1079

www.redp.uerj.br

autoridades do Estado ${ }^{88}$. André Ramos Tavares afirma que o acesso à justiça é o mais básico dos direitos humanos, não sendo útil apenas a proclamação de direitos sem a garantia de sua efetividade ${ }^{89}$.

A exigência da relação de pertinência, em virtude de construção jurisprudencial defensiva do Pretório Excelso, viola o preceito fundamental da inafastabilidade do controle jurisdicional ${ }^{90}$, prejudicando a efetiva tutela de direitos coletivos, e configurando, assim, uma norma constitucional inconstitucional ${ }^{91}$.

Otto Bachof assevera que alguns princípios constitucionais são tão elementares e evidentes que constituem um direito anterior à própria Constituição, exigindo garantia pelo legislador constitucional e pela Suprema Corte ${ }^{92}$.

É inconstitucional, por violar a norma constitucional expressa no artigo $5^{\circ}$, inciso XXXV, da Constituição Federal de 1988, qualquer impedimento ao exame judicial, por consequência de lesão ou ameaça a direitos ${ }^{93}$.

A Constituição Federal de 1988 não estabelece impedimentos ao controle jurisdicional, e, sendo praticada uma violação a direitos fundamentais, torna-se imprescindível o controle de constitucionalidade das leis e atos normativos primários sob pena de extinção indireta do próprio direito fundamental lesado ${ }^{94}$. Essa eliminação da fiscalização judicial de constitucionalidade dos atos do Poder Público viola o princípio do direito fundamental à efetivação da Constituição, pois impede a aplicação da supremacia da Constituição ${ }^{95}$.

O direito fundamental à efetivação da Constituição "consiste no fundamental direito que todos têm de ver a Constituição observada em sua plenitude, ou melhor, efetivada e

88 JUNOY, Joan Picó I. Las Garantías Constitucionales del Proceso. Barcelona: Jose María Bosch Editor, 1997. p. 17; COMOGLIO, Luigi Paolo; FERRI, Corrado; TARUFFO, Michele. Lezioni Sul Processo Civile. 4.ed. v. I. Bologna: Il Mulino, 2006. p. 101.

${ }^{89}$ TAVARES, André Ramos. Teoria da Justiça Constitucional, op. cit., p. 409.

${ }^{90}$ Art. $5^{\circ}$, XXXV, Constituição Federal de 1988.

${ }^{91}$ BACHOF, Otto. Normas Constitucionais Inconstitucionais? Tradução de José Manuel M. Cardoso da Costa. Coimbra: Livraria Almedina, 1994. p. 10 - 12.

${ }^{92}$ BACHOF, Otto. Normas Constitucionais Inconstitucionais? Op. cit., p. 23.

${ }^{93}$ ROSAS, Roberto, op. cit., p. 206.

${ }^{94}$ KRIELE, Martin. Introducción a la Teoría del Estado: fundamentos históricos de la legitimidad del Estado constitucional democrático. Buenos Aires: Depalma, 1980, p. 159 - 160; FERREIRA, Olavo Augusto Vianna Alves. Sistema Constitucional das Crises, op. cit., p. 188 - 189.

95 FERREIRA, Olavo Augusto Vianna Alves. Sistema Constitucional das Crises: restrições a direitos fundamentais. São Paulo: Método, 2009, p. 189. 
Revista Eletrônica de Direito Processual - REDP.

Rio de Janeiro. Ano 16. Volume 23. Número 1. Janeiro a Abril de 2022

Periódico Quadrimestral da Pós-Graduação Stricto Sensu em Direito Processual da UERJ

Patrono: José Carlos Barbosa Moreira (in mem.). ISSN 1982-7636. pp. 1053-1079

www.redp.uerj.br

concretizada, a fim de que se possibilite, até mesmo, que outros direitos fundamentais se desenvolvam e se realizem" 96.

Logo, esta jurisprudência defensiva da Suprema Corte ${ }^{97}$, pode consistir em requisito limitador à efetivação da cidadania ${ }^{98}$, acarretando verdadeira desnaturação do controle abstrato de constitucionalidade ${ }^{99}$.

$\mathrm{O}$ acesso à cidadania corresponde no principal poder-dever do Estado Democrático de Direito, que ocorre pela efetivação dos direitos fundamentais ${ }^{100}$. Conforme Hanna Arendt, cidadania consiste na existência de um direito a ter direitos ${ }^{101}$.

A necessidade de se comprovar a relação de pertinência entre o ato impugnado e as finalidades do órgão ou entidade, por parte dos legitimados especiais, pode consagrar uma imposição algumas vezes até mais rígida que a "necessária para admissão de processos subjetivos de legitimação extraordinária (substituição processual)"102.

A restrição ocasionada pela pertinência temática não se compatibiliza com a natureza objetiva da fiscalização abstrata de normas, pois cria uma infundada diferenciação sem previsão expressa na Constituição Federal, entre os legitimados universais e especiais ${ }^{103}$.

Uma comparação faz-se necessária: no Mandado de Segurança Coletivo não se exige uma relação de pertinência entre o ato impugnado e as finalidades do impetrante, é cabível o questionamento sobre a necessidade da pertinência temática em um processo de natureza objetiva $^{104}$. "Se a diretriz da nova Constituição foi à abertura do acesso ao processo de

\footnotetext{
${ }^{96}$ CUNHA JÚNIOR, Dirley da. Controle Judicial das Omissões do Poder Público: em busca de uma dogmática constitucional transformadora à luz do direito fundamental à efetivação da Constituição. São Paulo: Saraiva, 2004, p. 256.

${ }^{97}$ Informativo n. 307 do STF; ADI n. 2.652 - DF; ADI n. 2.656 - SP; ADI n. 1.096 - RS; ADI n. 1.519 - AL.

${ }^{98}$ ALMEIDA, Gregório Assagra de, op. cit., p. 58; CIANCI, Mirna; ALMEIDA, Gregório Assagra de, op. cit., p. 29.

${ }^{99}$ MENDES, Gilmar Ferreira. Jurisdição Constitucional, op. cit., p. 197 - 199.

100 SILVA, Juvêncio Borges(coord); LEHFELD, Lucas de Souza (coord). Constituição, Cidadania e a Concretização dos Direitos Coletivos. Curitiba: Juruá, 2015. p. 17.

${ }^{101}$ ARENDT, Hanna. Origens do Totalitarismo. Tradução de Roberto Raposo. São Paulo: Companhia das Letras, 1990, p. $330-336$.

${ }^{102}$ BERNARDES, Juliano Taveira. Controle Abstrato de Constitucionalidade, op. cit., p. 372.

${ }^{103}$ MENDES, Gilmar Ferreira. Jurisdição Constitucional, op. cit., p. 196 - 197.

${ }^{104}$ BERNARDES, Juliano Taveira. Controle Abstrato de Constitucionalidade, op. cit., p. 372.
} 
controle abstrato de constitucionalidade, não se poderiam estabelecer freios que a contrariassem por meio de jurisprudência restritiva"105.

No julgamento da Ação Direta de Inconstitucionalidade $\mathrm{n}^{0}$ 3.691, ajuizada pela Associação Nacional dos Procurados do Trabalho (ANTP) e pela Associação Nacional dos Magistrados da Justiça do Trabalho (ANAMATRA) contra os artigos $5^{\circ}$, caput, parágrafo único, e 18, da Lei $\mathrm{n}^{0}$ 11.442/2007, que dispõe sobre o transporte rodoviário de cargas, o plenário do Supremo Tribunal Federal, seguindo o voto da ministra Rosa Weber, flexibilizou o requisito jurisprudencial ${ }^{106}$ da pertinência temática para a proposição de ações de controle de constitucionalidade, prevalecendo a tese de que a pertinência temática poderia ser indireta.

Nesse caso, o entendimento foi de que as associações possuem legitimidade para propor a Ação Direta de Inconstitucionalidade, pois seus associados são diretamente afetados pela norma impugnada em virtude dos inúmeros questionamentos na Justiça do Trabalho sobre vínculo de emprego de motoristas de caminhão, que diz respeito ao alcance da competência daquele ramo do Judiciário. Em sentido contrário, ficaram vencidos os votos dos Ministros Luís Roberto Barroso, Celso de Mello, Marco Aurélio Mello e Luiz Edson Fachin, que compreenderam pela ausência da legitimidade das entidades de classe, em razão da falta de pertinência temática ${ }^{107}$.

O Ministro Gilmar Mendes, nesse julgamento, manifestou-se pela supressão da pertinência temática, por entender se tratar de um requisito jurisprudencial da Suprema Corte, enquanto outros Ministros, como Luís Roberto Barroso, a reafirmaram, sob a possibilidade de se permitir acesso praticamente irrestrito ao Pretório Excelso.

\section{CONSIDERAÇÕES FINAIS}

\footnotetext{
${ }^{105}$ Id., Ibid., p. 369.

${ }^{106}$ Conforme a ADI n ${ }^{\circ} 1.407$ MC e a ADPF n ${ }^{\circ} 144$, a despeito da ausência de amparo constitucional ou legal que justifique tal exigência, o requisito da pertinência temática é necessário sob pena de se ampliar excessivamente o número de ações constitucionais ajuizadas no Pretório Excelso.

${ }^{107}$ Para os Ministros, a legitimidade para propor ações de controle depende da ligação do tema em discussão com as finalidades do autor.
} 
A pertinência temática, conforme a jurisprudência do Supremo Tribunal Federal, consiste na imprescindibilidade de comprovação da relação de pertinência entre o objeto da ação e os interesses institucionais pelas autoridades legitimadas no artigo 103, incisos IV, V e IX, da Constituição Federal de 1988, para o ingresso de ação do controle abstrato de constitucionalidade. Extrai-se esse precedente dos seguintes julgados da Suprema Corte: Ação Direta de Inconstitucionalidade $\mathrm{n}^{\circ}$ 2.652/DF; Ação Direta de Inconstitucionalidade $\mathrm{n}^{\circ}$ 2.656/SP; Ação Direta de Inconstitucionalidade $\mathrm{n}^{\mathrm{o}}$ 1.096/RS; e Ação Direta de Inconstitucionalidade $\mathrm{n}^{\mathrm{o}} 1.519 / \mathrm{AL}$.

O controle abstrato de constitucionalidade é um processo de natureza objetiva que tem por finalidade a defesa da ordem constitucional, não estando vinculado a qualquer situação jurídica de caráter individual ou concreto. Nesse procedimento não há partes, e, em tese, inexiste uma lide. Não há a observância ao princípio do contraditório. Além disso, na fiscalização abstrata de constitucionalidade, os interesses processuais são exclusivamente objetivos, não sendo permitida qualquer titularidade desses.

A imposição da pertinência temática, como jurisprudência restritiva da Suprema Corte, para o ingresso de ação do controle abstrato de constitucionalidade, pelos legitimados especiais, caracteriza uma atuação ativista.

O ativismo judicial condiz na intervenção do Poder Judiciário em questões que não são de sua competência típica, mas sim dos Poderes Legislativo ou Executivo, por meio de uma construção jurisprudencial para a prestação jurisdicional em consequência da omissão legislativa ou executiva.

Essa atuação atípica e ativista acarreta um verdadeiro desempenho inoperante da função jurisdicional do Estado para a defesa de direitos coletivos e efetivação da cidadania. A atuação jurisprudencial ativista do Pretório Excelso, em decorrência da omissão legal, distanciando-se de critérios hermenêuticos, infringe o postulado básico de Estado Democrático de Direito. Há, nessa hipótese, um grande afastamento da participação social no processo deliberativo do Poder Judiciário, em contrapartida da participação dos cidadãos no processo político através da democracia representativa. 
A participação do Amicus Curiae, a realização de audiências públicas e a maior difusão do rol de legitimados ativos para as ações diretas, sem a imprescindibilidade de comprovação da pertinência temática, poderiam assegurar uma ampla participação democrática, pela sociedade, no controle constitucional das leis e atos normativos.

O controle abstrato da constitucionalidade, como instrumento para a tutela de direitos coletivos, configura um procedimento extremamente relevante para a garantia da rigidez e supremacia constitucional. Assim, a determinação da comprovação da pertinência temática pela jurisprudência defensiva do Supremo Tribunal Federal ocasiona certa quebra na democracia participativa, pois obstaculiza o ingresso da ação de fiscalização abstrata de constitucionalidade por esses representantes.

Ademais, a imposição da pertinência temática caracteriza ofensa ao princípio constitucional da inafastabilidade da jurisdição, previsto no artigo $5^{\circ}$, inciso $\mathrm{XXXV}$, da Constituição Federal de 1988, uma vez que, além da previsão do rol taxativo do artigo 103 da Carta Magna de 1988 para ingresso com ação do controle abstrato de constitucionalidade, a pertinência temática dificulta aos legitimados especiais a propositura de ações neste procedimento, prejudicando a eficácia da tutela jurisdicional coletiva e a imprescindível proteção da cidadania.

Com a devida vênia, entende-se que este obstáculo ou entrave ao exame judicial, por consequência de lesão ou ameaça a direitos, é inconstitucional por violar a norma constitucional expressa no artigo 5º inciso XXXV, da Constituição Federal de 1988.

\section{REFERÊNCIAS:}

AGRA, Walber de Moura. Aspectos Controvertidos do Controle de Constitucionalidade. Salvador: Juspodvm, 2008.

ALMEIDA, Gregório Assagra de. Direito Processual Coletivo Brasileiro: um Novo Ramo do Direito Processual. São Paulo: Saraiva, 2003.

ARENDT, Hanna. Origens do Totalitarismo. Tradução de Roberto Raposo. São Paulo: Companhia das Letras, 1990. p. $330-336$. 
BACHOF, Otto. Normas Constitucionais Inconstitucionais? Tradução de José Manuel M. Cardoso da Costa. Coimbra: Livraria Almedina, 1994.

BARBERIS, Mauro. Neoconstitucionalismo, Democracia e Imperialismo de la Moral. In: CARBONELL, Miguel (Coord.). Neoconstitucionalismo(s). Madrid: Trotta, 2003.

BARROSO, Luís Roberto. O Controle de Constitucionalidade no Direito Brasileiro. 7. ed. rev. e atual. São Paulo: Saraiva, 2016.

BERNARDES, Juliano Taveira. Ação Direta de Inconstitucionalidade por Omissão (ADInO). Ações Constitucionais. 5. ed. rev., atual. e ampl. Salvador: Juspodvm, 2011.

BERNARDES, Juliano Taveira. Controle Abstrato de Constitucionalidade: elementos materiais e princípios processuais. São Paulo: Saraiva, 2004.

BLACK, Henry Campbell. Black's Law Dictionary. 5. ed. St. Paul: West Group, 1983.

BOBBIO, Norberto. A Era dos Direitos. Tradução de Carlos Nelson Coutinho. Rio de Janeiro: Elsevier, 2004.

CALAMANDREI, Piero. Instituciones de Derecho Procesal Civil. v. 1. Tradução de Santiago Sentis Melendo. Buenos Aires: EJEA, 1986.

CANOTILHO, J. J. Gomes. Direito Constitucional e Teoria da Constituição. 7. ed. Coimbra: Almedina, 2007.

CHIOVENDA, Giuseppe. Instituições de Direito Processual Civil. Tradução de J. Guimarães Menegale. 3. ed. São Paulo: Saraiva, 1969.

CIANCI, Mirna; ALMEIDA, Gregório Assagra de. Direito Processual do Controle da Constitucionalidade. São Paulo: Saraiva, 2011.

CINTRA, Antônio Carlos Araújo; DINAMARCO, Cândido Rangel; GRINOVER, Ada Pellegrini. Teoria Geral do Processo. 21. ed. rev. e atual. São Paulo: Malheiros, 2005.

CLÈVE, Clèmerson Merlin. A Fiscalização Abstrata da Constitucionalidade no Direito Brasileiro. 2. ed. rev., atual. e ampl. São Paulo: Revista dos Tribunais, 2000.

COMOGLIO, Luigi Paolo; FERRI, Corrado; TARUFFO, Michele. Lezioni Sul Processo Civile. 4.ed. v. I. Bologna: Il Mulino, 2006.

COMOGLIO, Luigi Paolo. Garanzie Costituzionali e "Giusto Processo" (modelli a confronto). Revista de Processo. São Paulo, vol. 90, p. 95 - 150, 1998. 
COSTA NETO, João. A abertura procedimental da jurisdição constitucional exercida pelos órgãos de cúpula: breves notas sobre Alemanha, Brasil e EUA. Revista Brasileira de Estudos Constitucionais - RBEC, Belo Horizonte, ano 6, n. 24, out./dez. 2012. Disponível em: http://www.bidforum.com.br/PDI0006.aspx?pdiCntd=91087.

CUNHA JÚNIOR, Dirley da. Controle Judicial das Omissões do Poder Público: em busca de uma dogmática constitucional transformadora à luz do direito fundamental à efetivação da Constituição. São Paulo: Saraiva, 2004.

DANTAS, Paulo Roberto de Figueiredo. Direito Processual Constitucional. 5. ed. rev. e amp. São Paulo: Atlas, 2014.

FERRAJOLI, Luigi. Pasado y futuro del Estado de Derecho. In: CARBONELL, Miguel (Coord.). Neoconstitucionalismo(s). Madrid: Trotta, 2003.

FERREIRA, Olavo Augusto Vianna Alves; BORGES, Daniela Meca. A Limitação Territorial da Coisa Julgada como Óbice ao Acesso à Justiça. Revista Opinião Jurídica. Fortaleza, ano 16, n. 23, p. 160 - 183, Jul./Dez. 2018.

FERREIRA, Olavo Augusto Vianna Alves. Controle de Constitucionalidade e seus Efeitos. 3. ed. rev. e atual. Salvador: JusPODIVM, 2016.

FERREIRA, Olavo Augusto Vianna Alves. Sistema Constitucional das Crises: restrições a direitos fundamentais. São Paulo: Método, 2009.

GERAIGE NETO, Zaiden. O Princípio da Inafastabilidade do Controle Jurisdicional: art. 5, inciso XXXV, da Constituição Federal. São Paulo: Revista dos Tribunais, 2003.

GREEN, Craig. An Intellectual History of Judicial Activism. Emory Law Journal, Atlanta, v. 58, n. 5, p. 1195 - 1263, 2009.

HÄBERLE, Peter. Hermenêutica Constitucional. A Sociedade Aberta dos Intérpretes da Constituição: Contribuição para a Interpretação Pluralista e "Procedimental" da Constituição. Tradução de Gilmar Ferreira Mendes. Porto Alegre: SAFE, 1997.

HALL, Kermit L. (Ed.). The Oxford Companion to the Supreme Court of the United States. New York: Oxford University Press, 1992.

JUNOY, Joan Picó I. Las Garantías Constitucionales del Proceso. Barcelona: Jose María Bosch Editor, 1997. 
KELSEN, Hans. Teoria Pura do Direito. São Paulo: Martins Fontes, 1999.

KMIEC, Keenan D. The Origin and Current Meanings of "Judicial Activism". California Law Review, v. 92, n. 5, p. 1441 - 1477, 2004.

KRIELE, Martin. Introducción a la Teoría del Estado: fundamentos históricos de la legitimidad del Estado constitucional democrático. Buenos Aires: Depalma, 1980.

LIMA, Rogério Medeiros Garcia de. Processo Civil e Direitos Fundamentais. Revista Paradigma. Ribeirão Preto/SP, a. XX, v. 24, n. 2, p. 57 - 70, Jul./Dez. 2015.

LUNARDI, Soraya. Teoria do Processo Constitucional: Análise de sua Autonomia, Natureza e Elementos. São Paulo: Atlas, 2013.

LUÑo, Antonio E. Pérez. Derechos Humanos, Estado de Derecho e Constitución. 2. ed. Madrid: Tecnos, 1986.

MARINONI, Luiz Guilherme. Técnica Processual e Tutela dos Direitos. São Paulo: Revista dos Tribunais, 2004.

MARSHALL, William P. Conservatism and the Seven Signs of Judicial Activism. University of Colorado Law Review, Chapel Hill, n. 73, p. 101 - 140, 2002.

MAXIMILIANO, Carlos. Hermenêutica e aplicação do direito. Rio de Janeiro: Forense, 1999.

MENDES, Gilmar Ferreira. Jurisdição Constitucional: o Controle Abstrato de Normas no Brasil e na Alemanha. 6. ed. São Paulo: Saraiva, 2014.

MERRIAM-WEBSTER. Merriam-Webster's Dictionary of Law. Massachusetts: MerriamWebster, 1996.

MOHÍNO, Juan Carlos Bayón. Derechos, Democracia y Constitución. In: CARBONELL, Miguel (Coord.). Neoconstitucionalismo(s). Madrid: Trotta, 2003.

MONTESANO, Luigi. La Garanzia Costituzionale del Contraddittorio e i Giudizi Civili di “Terza Via”. Rivista di Diritto Processuale. Padova, v. 55, n. 4, p. 929 - 947, out. 2000.

NERY JR., Nelson. Princípios do Processo Civil na Constituição Federal. 7. ed. rev. e atual. São Paulo: Editora Revista dos Tribunais, 2002. 
NUNES, Danilo Henrique; SILVEIRA, Sebastião Sérgio. A Banalização dos Princípios da Razoabilidade e da Proporcionalidade no Controle Difuso de Constitucionalidade e Separação de Poderes. Revista Eletrônica de Direito Processual - REDP. Rio de Janeiro, ano 13, vol. 20, n. 2, p. 74 - 95, Mai./Ago. 2019.

PÉREZ, Jesús González. El Derecho a la Tutela Jurisdiccional. 2. ed. Madrid: Civitas, 1989.

PERRY, Michael J. The Constitution in the Courts: Law or Politics? New York/Oxford: Oxford University Press, 1994.

PIOVESAN, Flávia. Proteção Judicial contra Omissões Legislativas: Ação Direta de Inconstitucionalidade por Omissão e Mandado de Injunção. São Paulo: Revista dos Tribunais, 1995.

RAMOS, Elival da Silva. Ativismo Judicial: Parâmetros Dogmáticos. São Paulo: Saraiva, 2010.

ROSAS, Roberto. Direito Processual Constitucional: princípios constitucionais do processo civil. 2. ed. rev., atual. e ampl. São Paulo: Editora Revista dos Tribunais, 1997.

SILVA, Juvêncio Borges(coord); LEHFELD, Lucas de Souza (coord). Constituição, Cidadania e a Concretização dos Direitos Coletivos. Curitiba: Juruá, 2015.

SILVESTRINI, João Pedro; GERAIGE NETO, Zaiden; VILELA, Thiago Ribeiro Franco. A Contribuiçãa do Código de Defesa do Consumidor na Tutela de Interesses Individuais e Coletivos. Revista Direito e Justiça: Reflexões Sociojurídicas. Santo Ângelo, v. 19, n. 34, p. 97 - 112, maio/agos. 2019.

STF. Estatísticas do STF. Disponível em: http://www.stf.jus.br/portal/cms/verTexto.asp?servico=estatistica\&pagina=CC_Geral.

TAVARES, André Ramos. Paradigmas do Judicialismo Constitucional. São Paulo: Saraiva, 2012.

TAVARES, André Ramos. Teoria da Justiça Constitucional. São Paulo: Saraiva, 2005.

TEIXEIRA, Min. Sálvio Figueiredo (Coord.). Reforma do Código de Processo Civil. São Paulo: Saraiva, 1996. 
TRINDADE, André Karam; OLIVEIRA, Rafael Tomaz de. O Ativismo Judicial na Débâcle do Sistema Político: sobre uma hermenêutica da crise. Revista Eletrônica do Curso de Direito da UFSM, Santa Maria, RS, v. 11, n. 2, p. 751 - 772, 2016.

TRINDADE, André Karam. O Ativismo Judicial à Brasileira e a Questão Penitenciária no Rio Grande do Sul. Revista da Faculdade de Direito do Sul de Minas, Pouso Alegre, v. 32, n. 1, p. 203 - 228, jan./jun. 2016.

ULLA, Juan Manuel López. Orígenes Constitucionales del Control Judicial de las Leyes. Madrid: Editorial Tecnos, 1999.

WALDRON, Jeremy. A Right-Based Critique of Constitutional Rights. Oxford Journal of Legal Studies, v. 13, n. 1, p. 18-51, 1993.

YOUNG, Ernest A. Judicial Activism and Conservative Politics. University of Colorado Law Review, v. 73, n. 4, p. 1139 - 1216, 2002.

ZANDONA, Sérgio Henriques; CAMPOS, Felipe Almeida. A Crise do Sistema Representativo na Tutela Processual Coletiva Brasileira. Revista Paradigma. Ribeirão Preto/SP, a. XXIV, v. 28, n. 1, p. 57 - 81, Jan./Abr. 2019.

ZAVASCKI, Teori Albino. Processo Coletivo: Tutela de Direitos Coletivos e Tutela Coletiva de Direitos. 7. ed. rev., atual. e ampl. São Paulo: Revista dos Tribunais, 2017. 